\title{
NK-KIR Gene Repertoire and Outcome of Patients with Acute Myeloid Leukemia after Allogeneic Hematopoietic Cell Transplantation from Unre- lated Donors
}

\author{
Wilasinee Chainonthee ${ }^{1, *}$, Martin Bornhäuser ${ }^{1}$, Monika Füssel ${ }^{2}$, Gerhard Ehninger ${ }^{1}$ and Ralf \\ Wassmuth $^{1,2}$ \\ ${ }^{I}$ Medizinische Klinik u. Poliklinik I, Universitätsklinikum Carl Gustav Carus der Technischen Universität Dresden, \\ Dresden, Germany \\ ${ }^{2}$ DKMS Life Science Lab GmbH, Germany
}

\begin{abstract}
In this retrospective study, the influence of donor and recipient KIR-gene content and their respective ligands including clinical parameters as potential confounding variables on the outcome of 150 acute myeloid leukemia (AML) patients undergoing allogenic hematopoietic cell transplantation (HCT) from unrelated donors was systematically investigated. There was no significant influence of KIR ligand mismatching and of donor/recipient KIR haplotype combinations on overall survival (OS), disease free survival (DSF), non-relapse mortality (NRM) and relapse. Isolated effects of KIR haplotypes, were detected for acute, chronic Graft versus Host Disease (aGvHD and cGvHD) as well as for the cumulative incidence of non-relapse mortality and relapse. The incidence of non-relapse mortality was evaluated in donor and recipient pairs harbouring KIR AA homozygosity $(\mathrm{AA} / \mathrm{Bx}$ : $\mathrm{p}=0.038, \mathrm{HR}=0.73,95 \% \mathrm{CI}=0.35-1.46$ and $\mathrm{AA} / \mathrm{AA}$ : $\mathrm{p}=0.043$, $\mathrm{HR}=0.64,95 \%$ CI $0.53-1-17$ ). Our data suggest that KIR genotyping may be useful in patients in whom several HLAidentical unrelated donors can be identified but is probably not necessary for the primary donor selection algorithm.
\end{abstract}

Keywords: KIR, stem cell transplantation, GvL.

\section{INTRODUCTION}

Natural killer (NK) cell effector function plays a pivotal role in cytotoxicity against tumor cells and control of tumor growth [1]. In allogeneic hematopoietic cell transplantation, NK cells may contribute to graft-versus-leukemia (GvL) effects [2-4]. NK cells are regulated by surface-expressed activating and inhibitory killer-cell-immunoglobulin-like receptors (KIR). The latter interact with human leukocyte antigen class I molecules (HLA) [5, 6]. To date 14 functional KIR genes and two pseudogenes have been identified [7] . Inhibitory KIRs interact mainly with HLA-C group 1 or group 2 molecule [8,9].

Until now, several different models have been put forward to account for the influence of KIR-ligands on HCT. i) In the ligand model, the absence of specific HLA ligands in the recipient for donor inhibitory KIR, enhances NK cell activity and supports GvL effects and is based on HLA-C ligand status (ligand-ligand model or "missing-self" theory). ii) In a second model, receptor-ligand model, based on the setting that donor's KIR genotype includes at least one inhibitory KIR gene that has no cognate ligand in the recipient,

*Address correspondence to this author at the Medizinische Klinik u. Poliklinik I, Universitätsklinikum Carl Gustav Carus der Technischen Universität Dresden, Fetscherstr. $74 \cdot 01307$ Dresden, Germany;

Tel: + 49351458 4706; Fax: + 49351458 5362;

E-mail: Wilasinee.Chainonthee@uniklinikum-dresden.de three different subgroups can be defined in this model: (a) the donor possesses 2DL2/2DL3 and the patients lacks HLA$\mathrm{C}$ ligand groups 1: (b) the donor is positive for 2DL1 and the patients lacks HLA-C group 2 or (c) the donor is positive for 3DL1 and the patients lacks Bw4. The impact of KIR-ligand incompatibility on the outcome of HCT remains controversial. Several reports have suggested that a KIR-epitope mismatch is associated with improved OS and decreased relapse incidence [10-13], whereas some studies published the detrimental effect of the incompatibility of KIR-epitopes incompatibilities [14-20]. iii) The third model takes into consideration of the patient's and donor KIR genotype [20-22], or number of donor's activating KIR $[18,16]$.

\section{MATERIAL AND METHODS}

\section{Hematopoietic Stem Cell Transplantation}

The aim of this retrospective study was to systematically analyse the contribution of KIR genes and their respective ligands on the outcome of AML patients undergoing allogenic HCT from unrelated donors including clinical parameters as potential confounding variables.

This retrospective study included a total of 150 patients with acute myeloid leukemia (AML) who had received allogeneic HCT at the Transplant Center of the Department of Medicine I of the University Hospital Dresden between 1998 and 2006. The patient's characteristics are summarized in Table 1. 
In 139 cases, patients were transplanted with G-CSFstimulated peripheral blood stem cells (PBSC) while bone marrow (BM) was used in 11 cases. In vivo T-cell depletion was applied in 29 cases. The conditioning regimen was standard myeloablative and consisted mainly of total body irradiation (TBI) (12Gy) and cyclophosphamide $(120 \mathrm{mg} / \mathrm{kg})$ or busulfan $(14-16 \mathrm{mg} / \mathrm{kg}$ ) and fludarabine. Reduced intensity protocols, i.e. TBI $\leq 6 \mathrm{~Gy}$, busulfan $\leq 8 \mathrm{mg} / \mathrm{kg}$ or cyclophosphamide $\leq 60 \mathrm{mg} / \mathrm{kg}$ were used in 7 transplantations. For the prophylaxis and treatment of graft-versus-host disease cyclosporine A, tacrolimus, mycophenolatmofetil, everolimus and methotrexate was used.

Table 1. Patients Characteristic

\begin{tabular}{|c|c|}
\hline Patient Characteristic & Data \\
\hline Number of patient & 150 \\
\hline \multicolumn{2}{|l|}{ Sex } \\
\hline Male & 82 \\
\hline Female & 68 \\
\hline Median age, years (range) & $53(18-76)$ \\
\hline Mean of follow-up & $23.4(0.7-87.9)$ months \\
\hline \multicolumn{2}{|l|}{ Diagnosis } \\
\hline AML & 150 \\
\hline \multicolumn{2}{|l|}{ Transplantation status } \\
\hline Complete remission $1 /$ Complete remission 2 & 81 \\
\hline Refractory/Relapse & 53 \\
\hline \multicolumn{2}{|l|}{ HLA compatibility } \\
\hline Mismatch & 25 \\
\hline Match & 125 \\
\hline \multicolumn{2}{|l|}{ Stem cell source } \\
\hline PBSC & 139 \\
\hline Bone marrow & 11 \\
\hline \multicolumn{2}{|l|}{ Conditioning Regimen } \\
\hline Standard & 143 \\
\hline Reduced Intensity & 7 \\
\hline T-cell Depletion & 29 \\
\hline KIR- receptor-ligand compatibility matched & 68 \\
\hline mismatched & 82 \\
\hline \multicolumn{2}{|l|}{ Donor/Recipient KIR haplotype } \\
\hline $\mathrm{AA} / \mathrm{AA}$ & 15 \\
\hline $\mathrm{AA} / \mathrm{Bx}$ & 32 \\
\hline $\mathrm{Bx} / \mathrm{AA}$ & 24 \\
\hline $\mathrm{Bx} / \mathrm{Bx}$ & 79 \\
\hline \multicolumn{2}{|l|}{ Recipient/donor HLA-C ligand status } \\
\hline $\mathrm{C} 1 \mathrm{C} 1 / \mathrm{C} 1 \mathrm{C} 1$ & 53 \\
\hline
\end{tabular}

\begin{tabular}{|l|c|}
\hline $\mathrm{C} 1 \mathrm{C} 1 / \mathrm{C} 1 \mathrm{C} 2$ & 2 \\
\hline $\mathrm{C} 1 \mathrm{C} 2 / \mathrm{C} 1 \mathrm{C} 1$ & 3 \\
\hline $\mathrm{C} 1 \mathrm{C} 2 / \mathrm{C} 1 \mathrm{C} 2$ & 72 \\
\hline $\mathrm{C} 2 \mathrm{C} 2 / \mathrm{C} 1 \mathrm{C} 2$ & 1 \\
\hline $\mathrm{C} 2 \mathrm{C} 2 / \mathrm{C} 2 \mathrm{C} 2$ & 19 \\
\hline
\end{tabular}

\section{Genotyping for KIR and HLA-C Ligand}

\section{KIR Genotyping}

The presence and the absence of 14 KIR genes in donor and recipient including KIR2DL1, 2DL2, 2DL3, 2DL4, 2DL5, 3DL1, 3DL2, 3DL3, 2DS1, 2DS2, 2DS3, 2DS4, 2DS5, 3DS1, and two pseudogenes, 2DP1 and 3DP1 were analysed by sequence-specific-primer polymerase chain reaction (SSP-PCR) from archived DNA samples using whole genome amplification as previously described [22].

\section{HLA-C ligand Genotyping}

KIR haplotype were assigned according to McQueen and coworkers [21]. The distinction of HLA-C ligand groups 1 (N80) and 2 (K80) was also performed by SSP-PCR and HLA-C ligand status was assigned following the protocol of Frohn and coworkers [23].

\section{Statistical Analysis}

The following outcomes parameters were investigated in this study: overall survival (OS), disease- free survival (DFS), cumulative incidence of relapse and non-relapse mortality, incidence of acute and chronic GvHD.

For the later analysis, death from other causes than AML and relapse were regarded as competing risk, the same was true for death and the incidence of aGvHD and cGvHD. Whereas OS and DFS was assessed by Kaplan-Meier survival analysis and compared by using log-rank tests, nonrelapse mortality and incidence of relapse and aGvHD were analyzed by cumulative incidence estimation. The incidence of cGvHD was calculated using crosstabulation (ChiSquare). Acute and chronic GvHD were diagnosed and graded using established criteria [24, 25]. aGvHD defines development of grade 1-4 GvHD during the first 100 days after transplantation. cGvHD was defined as GvHD occurring more than 100 days post-transplantation. McNemar's test was used for pairwise comparison of KIR gene frequencies in patients and donors. In addition, clinical variables, i.e. remission status, transplant source, transplant manipulation, conditioning regimen, sex-status, CMV-status and HLA match were considered as potential confounding variables and their contribution were also assessed. All statistical procedures were carried out as implemented in SPSS, version 16 (SPSS Inc., Chicago, IL, USA). In this report any p-value < 0.05 is regarded as statistically significant. No attempt was made to adjust the $\mathrm{p}$ values in this study.

\section{RESULTS}

\section{Influence of Clinical Variables on the HSCT Outcome}

Univariate analysis revealed that HLA matching contributed significantly to a better outcome. For OS, 44.29 vs. 
Table 2. Pairwise Comparison of KIR gene Frequencies in Patients and Donors

\begin{tabular}{|c|c|c|c|c|c|c|}
\hline \multirow[b]{2}{*}{ KIR Genes } & \multicolumn{4}{|c|}{ Donor/Recipient } & \multirow[b]{2}{*}{ Chi-Square } & \multirow[b]{2}{*}{ p-value } \\
\hline & $(+/+)$ & $(-/-)$ & $(+/-)$ & $(-/+)$ & & \\
\hline 2DL1 & 142 & 0 & 7 & 0 & & \\
\hline 2DL2 & 50 & 31 & 27 & 41 & 2.485 & 0.115 \\
\hline 2DL3 & 118 & 5 & 11 & 15 & 0.346 & 0.556 \\
\hline 2DL4 & 45 & 39 & 33 & 32 & 0.000 & 1.00 \\
\hline 2DS1 & 48 & 40 & 30 & 31 & 0.000 & 1.00 \\
\hline $2 \mathrm{DS} 2$ & 52 & 34 & 26 & 37 & 1.587 & 0.208 \\
\hline $2 \mathrm{DS} 3$ & 20 & 75 & 24 & 30 & 0.463 & 0.496 \\
\hline 2DS5 & 19 & 73 & 34 & 23 & 1.754 & 0.185 \\
\hline 3DS1 & 29 & 52 & 37 & 31 & 0.368 & 0.544 \\
\hline
\end{tabular}

Table 3. Univariate Analysis

\begin{tabular}{|c|c|c|c|c|c|c|}
\hline Independent Variables & Cohort Size & Outcome Parameter & Association & Data & Statistical Test & p-value \\
\hline \multicolumn{7}{|l|}{ Clinical variables } \\
\hline \multirow[t]{2}{*}{ HLA-matching } & $125 / 150$ & OS & improved & 44.29 vs. 18.87 months & KM & 0.006 \\
\hline & $125 / 150$ & DFS & improved & 44.46 vs. 17.90 months & KM & 0.008 \\
\hline \multicolumn{7}{|l|}{$\underline{K I R \text { and KIR ligands }}$} \\
\hline \multicolumn{7}{|l|}{ Donor/recipient (KIR haplotype) } \\
\hline \multirow[t]{2}{*}{$\mathrm{Bx} / \mathrm{Bx}$} & $79 / 150$ & aGvHD & high incidence & 72.37 vs 54.29 & $\mathrm{CI}$ & 0.01 \\
\hline & $79 / 150$ & cGvHD & decreased & & $\mathrm{CT}$ & 0.04 \\
\hline \multirow[t]{2}{*}{$\mathrm{AA} / \mathrm{AA}$} & $15 / 150$ & cGvHD & increased & & $\mathrm{CT}$ & 0.007 \\
\hline & $15 / 150$ & mortality & high incidence & 53.33 vs 24.16 & $\mathrm{CI}$ & 0.04 \\
\hline $\mathrm{AA} / \mathrm{Bx}$ & $32 / 150$ & mortality & high incidence & 40.32 vs 23.18 & $\mathrm{CI}$ & 0.03 \\
\hline \multicolumn{7}{|c|}{ Recipient/donor (HLA-C ligand) status } \\
\hline $\mathrm{C} 2 \mathrm{C} 2 / \mathrm{C} 2 \mathrm{C} 2$ & $19 / 150$ & aGvHD & high incidence & 38.89 vs 67.19 & $\mathrm{CI}$ & 0.03 \\
\hline \multicolumn{7}{|c|}{ Number of donor's inhibitory KIR genes } \\
\hline donor $>$ recipient ( 2 genes $)$ & $10 / 150$ & aGvHD & increased & & $\mathrm{CT}$ & 0.04 \\
\hline \multicolumn{7}{|c|}{ Number of donor's activating KIR genes } \\
\hline donor $>$ recipient $(3$ genes $)$ & $15 / 150$ & aGvHD & increased & & $\mathrm{CT}$ & 0.03 \\
\hline donor $>$ recipient ( 4 genes $)$ & $9 / 150$ & aGvHD & increased & & $\mathrm{CT}$ & 0.04 \\
\hline \multicolumn{7}{|l|}{ Influence of single KIR genes } \\
\hline R2DL3 & $133 / 150$ & DFS & improved & & $\mathrm{KM}$ & 0.03 \\
\hline
\end{tabular}

CI: Cumulative incidence estimation, CT: Cross tabulation (Chi-square), KM: Kaplan-Meier analysis

\section{Table 4. Multivariate Analysis}

\begin{tabular}{|c|c|c|c|c|}
\hline & \multicolumn{3}{|c|}{ Overall Survival (OS) } & p-value \\
\hline $\begin{array}{l}\text { HLA-matching } \\
\text { HLA-matched }\end{array}$ & 125 & & & \\
\hline
\end{tabular}


Table 4. contd...

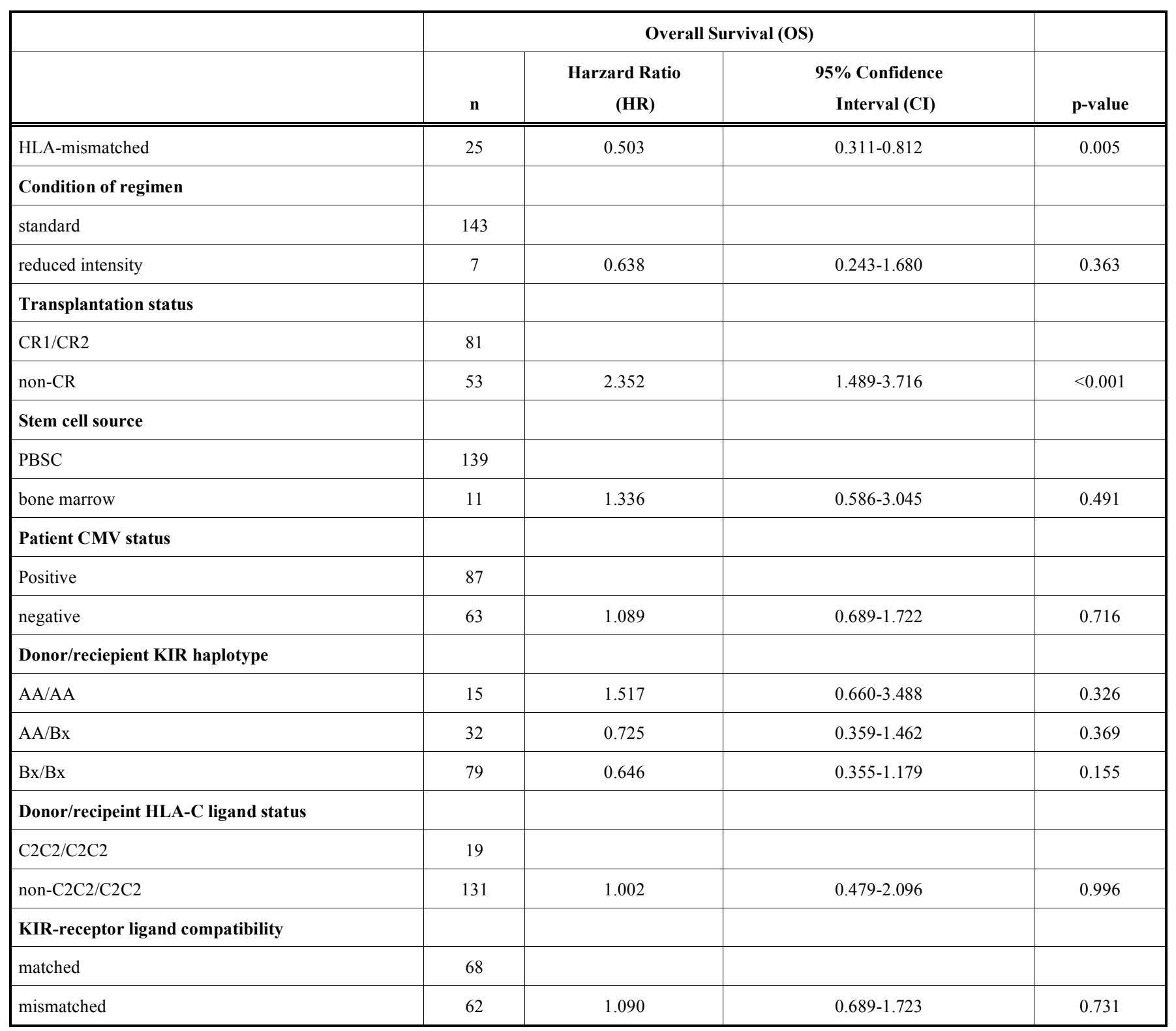

18.87 month survival $(\mathrm{p}=0.006)$ and for DFS 44.46 vs. 17.90 month survival $(\mathrm{p}=0.008)$ was noted (Table 3$)$.

Multivariate analysis showed a significant influence of HLA compatibility (HLA-matched vs mismatched: $p=0.005$, $\mathrm{HR}=0.503,95 \% \mathrm{CI}=0.311-0.812)$ and of transplantation status (CR vs non-CR: $\mathrm{p}<0.001, \mathrm{HR}=2.352,95 \% \mathrm{CI}=1.489$ 3.716) on OS (Table 4).

\section{KIR Gene Content and KIR Ligand Comparison.}

\section{KIR Gene Content}

Comparison of KIR gene frequencies revealed no significant differences in frequencies between donors and recipients as analyzed by pairwise comparison (Table 2 ).

\section{Recipient and Donor's HLA-C Ligand Status}

An incidence of aGvHD ( $\mathrm{p}=0.03)$ for donor/recipient involving $\mathrm{C} 2 \mathrm{C} 2 / \mathrm{C} 2 \mathrm{C} 2$ was noted.

\section{KIR Matching Analysis}

\section{$\underline{\text { KIR Ligand-Ligand Model }}$}

Based on HLA-B and -C analysis transplants were considered KIR-ligand mismatched when the recipient lacks KIR ligands present in the donor. There was no HLA-Bw4 ligand mismatch in $\mathrm{GvH}$ direction observed. For HLA-Cencoded ligands, a mismatch in $\mathrm{GvH}$ direction was observed in 3 cases.

\section{$\underline{\text { KIR Receptor-Ligand Model }}$}

KIR ligand mismatch was seen in $54.6 \%(82 / 150)$ of the cases on the receptor-ligand model. In the univariate and multivariate analyses KIR-ligand incompatibility revealed no significant impact on any end-points investigated in this study. 


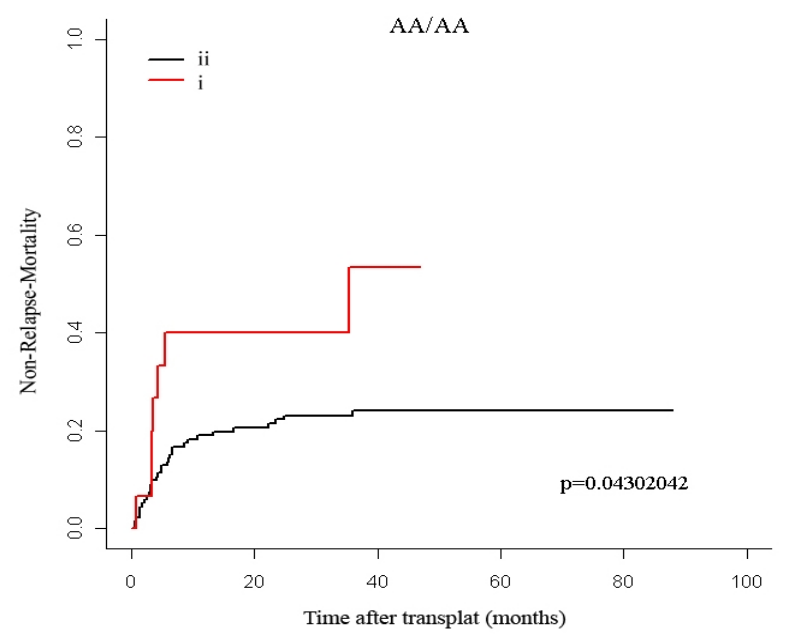

$\mathbf{A}$

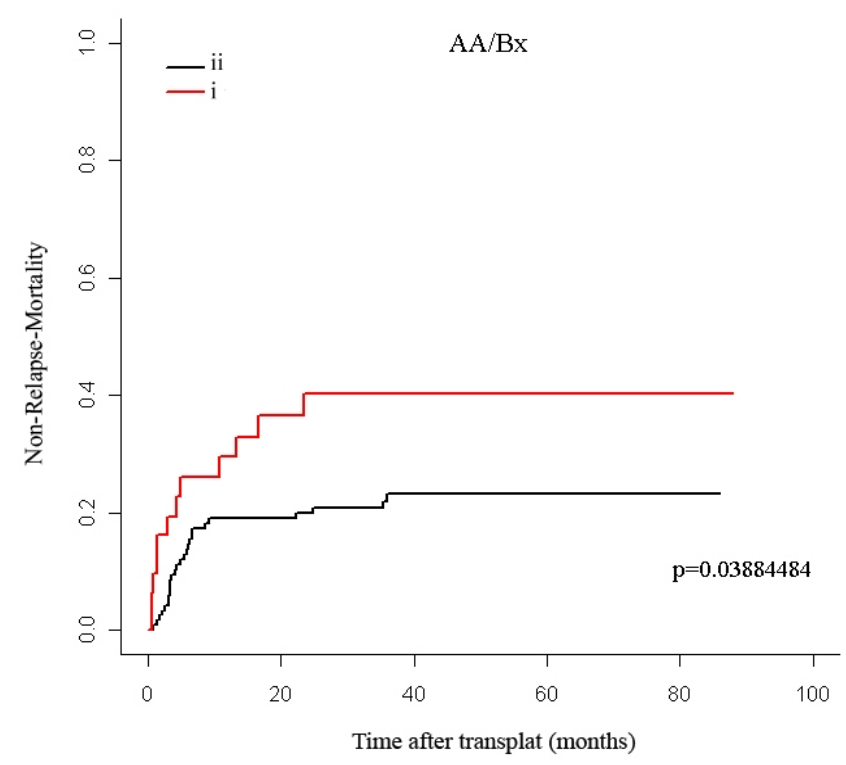

B

Fig. (1). Cumulative incidence estimation of non-relapse-mortality in donor involving KIR AA haplotype. (1A) Donor and recipient carrying KIR AA/AA haplotype: (i) donor and recipient having AA/AA KIR haplotype (n=15/150). (ii) donor and recipient with non AA/AA KIR haplotype (n=135/150). (1B) Donor and patient having KIR AA/Bx haplotype: (i) donor and recipient classified to AA/Bx KIR haplotype $(n=32 / 150)$. (ii) donor and patient with non $\mathrm{AA} / \mathrm{Bx}(\mathrm{n}=118 / 150)$.

\section{KIR haplotype Analysis}

The influence of donor and recipient KIR genotype on OS, DFS, a/cGvHD, NRM and relapse was analyzed for the following combinations of donor/recipient genotype AA/AA, $\mathrm{AA} / \mathrm{Bx}, \mathrm{Bx} / \mathrm{AA}$ and $\mathrm{Bx} / \mathrm{Bx}$. There was no association of donor/recipient KIR genotype on OS and DFS. Analyses with regard to NRM: the donors carrying KIR AA Haplotype was associated with non-relapse mortality (AA/Bx: $\mathrm{p}=0.03$, $\mathrm{HR}=0.73, \quad 95 \% \quad \mathrm{CI}=0.35-1.46$ and $\mathrm{AA} / \mathrm{AA}: \quad \mathrm{p}=0.04$, $\mathrm{HR}=0.64,95 \% \mathrm{CI}=0.35-1.17$ ) (Fig. 1). Analyses with regard to acute and chronic GvHD: high incidence of aGvHD $(\mathrm{p}=0.012, \mathrm{HR}=0.646,95 \% \mathrm{CI}=0.055-1.179)$ was noted for donors and patients with $\mathrm{Bx} / \mathrm{Bx}$ combination. The occurrence of cGvHD $(\mathrm{p}=0.007)$ was observed in recipient and donor involving AA/AA combination.

\section{Quantitative Distribution of Inhibitory and Activating KIR} $\underline{\text { Receptors }}$

When the distribution of inhibitory and activating genes in donors and recipients was compared, no significant heterogeneity was seen. An increased risk of aGvHD ( $p=0.04)$ and the number of donor and recipient inhibitory genes was 
observed when donors had two inhibitory KIR genes in excess of the recipient. There was an increased occurrence of aGvHD and the number of activating genes noted when donors had three $(p=0.03)$ or four $(p=0.04)$ activating KIR genes in excess of the patient.

KIR2DL3 in recipient was the single gene that significantly effect DFS $(\mathrm{p}=0.03)$.

\section{DISCUSSION AND CONCLUSION}

Our results indicated no significant impact of the recipient KIR HLA-C ligand status on OS, DFS, NRM and relapse while a high incidence of aGvHD $(\mathrm{p}=0.03)$ for donor/recipient involving $\mathrm{C} 2 \mathrm{C} 2 / \mathrm{C} 2 \mathrm{C} 2$ was noted. Several studies described inferior OS and DFS in the presence of HLA$\mathrm{C} 2$ in recipient $[10,26,27]$. This may be related to the reconstitution of NK cells after HCT as the C1-component NK cell (KIR2DL2/3) is expressed earlier and at higher frequency compared to the C2- component NK cell (KIR2DL1) [28]. Lastly, an inferior OS $(\mathrm{p}=0.01)$ and a higher rate of relapse $(\mathrm{p}=0.04)$ in recipients being $\mathrm{C} 1 \mathrm{C} 2$ heterozygous was seen in comparison to $\mathrm{C} 1$ or $\mathrm{C} 2$ homozygous patients [27].

In contrast to the ligand-ligand model which only includes the HLA typing, both the KIR gene content and the HLA typing are considered in the receptor-ligand model. Although several studies suggested that KIR-ligand incompatibility should be considered for donor selection in HCT, the role of KIR-ligand mismatching in HCT is still controversial. The reasons for the discrepancy in the results of KIR-ligand mismatching on the outcome of HCT in literature may be related with the small sized and heterogeneous cohorts analysed. Furthermore, in some studies KIR typing was not performed, only HLA typing result (ligand-ligand model) was used to predict KIR epitope incompatibility. As KIR genes are located on chromosome $19 \mathrm{q} 13.4$ and segregate independently from HLA genes on chromosome 6 . Therefore, assumptions, based on HLA typing do not reliably predict, KIR ligand incompatibility because of the putative lack of the corresponding gene in donor. This fact was supported by recent work of Leung and coworkers. The prediction of the risk of relapse was more accurate using the receptor-ligand model than with the ligand-ligand model [29].

Furthermore, Witt and co-worker suggested that the impact of NK-alloreactivity is strongly dependent on transplant protocol. Infusion of a very high dose of hematopoietic stem cells and ex-vivo T-cell depletion are potential prerequisites for higher NK cytotoxicity [30]. In regard to the transplant protocol, Giebel and coworkers have reported a benefit of alloreactivity of NK when antihymocyte globulin (ATG) in vivo T-cell depletion of donor and recipient was performed. However, this was not confirmed in other studies [14-16].

Several studies have indicated an influence of KIR gene and haplotype distribution on the outcome of HCT. Our results indicated that transplantation using donor having KIR AA haplotype leads to increase NRM (Fig. 1). The incidence of aGvHD, but decreased cGvHD was noted for donors and recipients carrying $\mathrm{Bx} / \mathrm{Bx}$ KIR haplotype. Cooley and coworkers reported that transplantation from donors carrying at least one B haplotype was associated with a significantly improved relapse free survival and overall survival compared to transplantation of grafts from type A haplotype donors [31]. Another study of Cooley indicated a significantly reduced relapse incidence and thus improved DSF in AML but not ALL patients transplanted from donors having 2 or more $B$ gene-content motifs [32]. Another study has also suggested a benefit for A haplotype homozygous recipients receiving grafts from donors having at least one B haplotype [33]. This is in the line with our findings. Of course, the larger size of the cohort reported by Cooley increases its statistical power compared to the current analysis. In addition, we describe an increased incidence of aGvHD in donors and recipient pairs carrying KIR B heterozygosity. In contrast to the aforementioned study, the poorest survival due to aGvHD was noted in haplotype $\mathrm{B}$ heterozygous donor/haplotype A homozygous recipient ( $\mathrm{p}=0.005)$ [21].

Lastly, when investigating the distribution of inhibitory and activating genes in donor and recipient, we found an association of aGvHD with the number of activating KIR genes in the respective donor. A high number of donor activating KIR genes ( 3 and 4 genes more than recipient) is a risk factor for the occurrence of aGvHD $(\mathrm{p}=0.03$ and 0.04 , respectively). Comparable results have been reported by other authors [18]. A high relapse rate in the presence of a high number of donor activating KIR genes (activating KIR $\geq 4$ versus activating $\mathrm{KIR} \leq 3, \mathrm{p}=0.002$ ) and a low number of donor activating genes associated with reduced disease free survival. Furthermore a higher rate of relapse was found in the presence of KIR B haplotype in the donor being homozygous $(\mathrm{BB})$ or heterozygous $(\mathrm{AB})$ compared to donors having an A haplotype [16]. These observations were consistent with the finding of Schellekens and her group who reported a high relapse rate may occur when patients have more activating KIR genes [34]. The presence of activating genes in the donor leads to enhanced alloreactivity of donor-derived NK cells. This could theoretically support GvL effects and thereby improve OS. On the other hand the immune reconstitution could be impaired and the risk of GvHD may be increased. This is in agreement with our results as the most favorable OS, but increased incidence of aGvHD was observed in donors and recipients having the Bx haplotype which implies a higher number of activating KIR in the donor.

Several studies have described a benefit for single KIR genes on HST outcome [20, 21, 34]. In our study recipient 2DL3 significantly improved DFS. A reduced risk of developing severe fibrosis after liver transplantation in presence of recipient KIR 2DL3 was published by de Arias and coworker [35]. In contrast to our study the absence of recipient 2DL3 and 2DL1 was reported to be associated with improved OS [34]. The underlying mechanism for the influence of patient KIR2DL3 on HCT outcome is still unknown. However, the influence of individual KIR genes on outcome of HCT should be carefully interpreted, as KIRs are prone to high linkage disequilibrium.

Strategies for donor selection incorporating KIR genotypes are still under development due to the uncertain underlying mechanism and the partly conflicting results reported for KIR-ligand mismatches. The absence of a ligand for the corresponding inhibitory KIRs in the recipient triggers NK- 
alloreactivity. However, KIR2DS1 and KIR2DS2 have been reported to interact with HLA-C group 2 and group 1 respectively $[36,37]$. When both inhibitory and activating KIRs interact with the cognate ligand, alloreactivity is determined by the balance of the signal. Most ligands of activating KIR have been not identified, thus it is difficult to extrapolate these algorithms. Our results suggest that KIR genotyping may provide additional information which could be utilized in selected cases for donor/recipient selection. Overall, however, controversies still prevail arguing against routine KIR typing of donor and recipient before allogeneic HCT.

\section{CONFLICT OF INTEREST}

The authors confirm that this article content has no conflicts of interest.

\section{ACKNOWLEDGEMENTS}

This study was supported by an institutional grant from DKMS Life Science Lab GmbH and the Deutsche Forschungsgemeinschaft (SFB 655). The authors would like thank Cathrin Theuser for her kind assistance in data analysis.

\section{REFERENCES}

[1] Velardi A. Role of KIRs and KIR ligands in hematopoietic transplantation. Curr Opin Immunol 2008; 20: 581-7.

[2] Ruggeri L, Capanni M, Urbani E, et al. Effectiveness of donor natural killer cell alloreactivity in mismatched hematopoietic transplants. Science 2002; 295: 2097-100.

[3] Giebel S, Locatelli F, Lamparelli T, et al. Survival advantage with KIR ligand incompatibility in hematopoietic stem cell transplantation from unrelated donors. Blood 2003;102: 814-9.

[4] Beelen DW, Ottinger HD, Ferencik S, et al. Genotypic inhibitory killer immunoglobulin-like receptor ligand incompatibility enhances the long-term antileukemic effect of unmodified allogeneic hematopoietic stem cell transplantation in patients with myeloid leukemias. Blood 2005; 105: 2594-600.

[5] Middleton D, Curran M, Maxwell L. Natural killer cells and their receptors. Transpl Immunol 2002;10:147-164.

[6] Dupont B, Hsu KC. Inhibitory killer Ig-like receptor genes and human leukocyte antigen class I ligands in haematopoietic stem cell transplantation. Curr Opin Immunol 2004;16: 634-43.

[7] Marsh SG, Parham P, Dupont B, et al. Killer-cell immunoglobulinlike receptor (KIR) nomenclature report, 2002. Hum Immunol 2003; 64: 648-54.

[8] Colonna M, Samaridis J. Cloning of immunoglobulin-superfamily members associated with HLA-C and HLA-B recognition by human natural killer cells. Science 1995; 268: 405-8.

[9] Moretta A, Biassoni R, Bottino C, et al. Natural cytotoxicity receptors that trigger human NK-cell-mediated cytolysis. Immunol Today 2000; 21: 228-34.

[10] Cook MA, Milligan DW, Fegan CD, et al. The impact of donor KIR and patient HLA-C genotypes on outcome following HLAidentical sibling hematopoietic stem cell transplantation for myeloid leukemia. Blood 2004; 103: 1521-6.

[11] Hsu KC, Keever-Taylor CA, Wilton A, et al. Improved outcome in HLA-identical sibling hematopoietic stem-cell transplantation for acute myelogenous leukemia predicted by KIR and HLA genotypes. Blood 2005; 105: 4878-84.

[12] Ruggeri L, Mancusi A, Capanni M, et al. Donor natural killer cell allorecognition of missing self in haploidentical hematopoietic transplantation for acute myeloid leukemia: challenging its predictive value. Blood 2007;110: 433-40.

[13] Verheyden S, Schots R, Duquet W, et al. A defined donor activating natural killer cell receptor genotype protects against leukemic relapse after related HLA-identical hematopoietic stem cell transplantation. Leukemia 2005;19:1446-51.

[14] Farag SS, Bacigalupo A, Eapen M, et al. The Effect of KIR Ligand Incompatibility on the Outcome of Unrelated Donor
Transplantation: A Report from the Center for International Blood and Marrow Transplant Research, the European Blood and Marrow Transplant Registry, and the Dutch Registry. Biol Blood Marrow Transplant 2006;12: 876-84.

[15] Schaffer M, Malmberg KJ, Ringden O, et al. Increased infectionrelated mortality in KIR-ligand-mismatched unrelated allogeneic hematopoietic stem-cell transplantation. Transplantation 2004;78:1081-5.

[16] Kroger N, Binder $\mathrm{T}$, Zabelina $\mathrm{T}$, et al. Low number of donor activating killer immunoglobulin-like receptors (KIR) genes but not KIR-ligand mismatch prevents relapse and improves diseasefree survival in leukemia patients after in vivo T-cell depleted unrelated stem cell transplantation. Transplantation 2006; 82: 102430 .

[17] Bornhauser M, Schwerdtfeger R, Martin H, et al. Role of KIR ligand incompatibility in hematopoietic stem cell transplantation using unrelated donors. Blood 2004;103: 2860-1.

[18] Bishara A, De Santis D, Witt CC, et al. The beneficial role of inhibitory KIR genes of HLA class I NK epitopes in haploidentically mismatched stem cell allografts may be masked by residual donor-alloreactive T cells causing GVHD. Tissue Antigens 2004; 63: 204-11.

[19] Miller JS, Cooley S, Parham P, et al. Missing KIR ligands are associated with less relapse and increased graft-versus-host disease (GVHD) following unrelated donor allogeneic HCT. Blood 2007;109: 5058-61.

[20] Gagne K, Brizard G, Gueglio B, et al. Relevance of KIR gene polymorphisms in bone marrow transplantation outcome. Hum Immunol 2002; 63: 271-80.

[21] McQueen KL, Dorighi KM, Guethlein LA, et al. Donor-recipient combinations of group A and B KIR haplotypes and HLA class I ligand affect the outcome of HLA-matched, sibling donor hematopoietic cell transplantation. Hum Immunol 2007; 68: 30923.

[22] Chainonthee W, Bottcher G, Gagne K, et al. Improved KIR gene and HLA-C KIR ligand sequence-specific primer polymerase chain reaction genotyping using whole genome amplification. Tissue Antigens 2010; 76: 135-43.

[23] Frohn C, Schlenke P, Ebel B, et al. DNA typing for natural killer cell inhibiting HLA-Cw groups NK1 and NK2 by PCR-SSP. J Immunol Methods 1998; 218: 155-60.

[24] Przepiorka D, Weisdorf D, Martin P, et al. 1994 Consensus Conference on Acute GVHD Grading. Bone Marrow Transplant 1995; 15: 825-8.

[25] Sullivan KM, Agura E, Anasetti C, et al. Chronic graft-versus-host disease and other late complications of bone marrow transplantation. Semin Hematol 1991; 28: 250-9.

[26] Giebel S, Nowak I, Wojnar J, et al. Impact of activating killer immunoglobulin-like receptor genotype on outcome of unrelated donor-hematopoietic cell transplantation. Transplant Proc 2006; 38: 287-91.

[27] Sobecks RM, Ball EJ, Maciejewski JP, et al. Survival of AML patients receiving HLA-matched sibling donor allogeneic bone marrow transplantation correlates with $\mathrm{HLA}-\mathrm{Cw}$ ligand groups for killer immunoglobulin-like receptors. Bone Marrow Transplant 2007; 39: 417-24.

[28] Fischer JC, Ottinger H, Ferencik S, et al. Relevance of C1 and C2 epitopes for hemopoietic stem cell transplantation: role for sequential acquisition of HLA-C-specific inhibitory killer Ig-like receptor. J Immunol 2007;178: 3918-23.

[29] Leung W, Iyengar R, Turner V, et al. Determinants of antileukemia effects of allogeneic NK cells. J Immunol 2004;172: 644-50.

[30] Witt CS, Christiansen FT. The relevance of natural killer cell human leucocyte antigen epitopes and killer cell immunoglobulinlike receptors in bone marrow transplantation. Vox Sang 2006; 90: 10-20.

[31] Cooley S, Trachtenberg E, Bergemann TL, et al. Donors with group B KIR haplotypes improve relapse-free survival after unrelated hematopoietic cell transplantation for acute myelogenous leukemia. Blood 2009;113:726-32.

[32] Cooley S, Weisdorf DJ, Guethlein LA, et al. Donor selection for natural killer cell receptor genes leads to superior survival after unrelated transplantation for acute myelogenous leukemia. Blood 2010;116: 2411-9.

[33] Symons HJ, Leffell MS, Rossiter ND, et al. Improved survival with inhibitory Killer Immunoglobulin Receptor (KIR) gene mismatches 
and KIR haplotype $\mathrm{B}$ donors after nonmyeloablative, HLAhaploidentical bone marrow transplantation. Biol Blood Marrow Transplant 2009; 16(4): 533-42.

[34] Schellekens J, Rozemuller EH, Petersen EJ, et al. Activating KIRs exert a crucial role on relapse and overall survival after HLAidentical sibling transplantation. Mol Immunol 2008; 45: 2255-61.

[35] de Arias AE, Haworth SE, Belli LS, et al. Killer cell immunoglobulin-like receptor genotype and killer cell immunoglobulin-like receptor-human leukocyte antigen C ligand compatibility affect the severity of hepatitis $\mathrm{C}$ virus recurrence after liver transplantation. Liver Transpl 2009;15: 390-9.

[36] Biassoni R, Pessino A, Malaspina A, et al. Role of amino acid position 70 in the binding affinity of p50.1 and p58.1 receptors for HLA-Cw4 molecules. Eur J Immunol 1997; 27: 3095-9.

[37] Biassoni R, Cantoni C, Falco M, et al. The human leukocyte antigen (HLA)-C-specific "activatory" or "inhibitory" natural killer cell receptors display highly homologous extracellular domains but differ in their transmembrane and intracytoplasmic portions. J Exp Med 1996; 183: 645-50.

Received: May 07, 2013

(C) Chainonthee et al.; Licensee Bentham Open.

This is an open access article licensed under the terms of the Creative Commons Attribution Non-Commercial License (http://creativecommons.org/licenses/by-nc/3.0/) which permits unrestricted, non-commercial use, distribution and reproduction in any medium, provided the work is properly cited. 